\title{
FITOREMEDIASI LIMBAH BUDIDAYA IKAN LELE (Clarias sp.) DENGAN KANGKUNG (Ipomoea aquatica) DAN PAKCOY (Brassica rapa chinensis) DALAM SISTEM RESIRKULASI
}

\section{PHYTOREMEDIATION OF CATFISH (Clarias sp.) FARMING WASTE WITH WATER SPINACH (Ipomoea aquatica) AND PAKCHOY (Brassica rapa chinensis) IN RECIRCULATION SYSTEMS}

\author{
Hefni Effendi ${ }^{11^{*}}$, Bagus Amalrullah Utomo ${ }^{1)}$, Giri Maruto Darmawangsa ${ }^{2)}$, Rebo Elfida Karo-Karo ${ }^{3)}$
}

(Diterima tanggal 05-02-2016; Disetujui tanggal 15-02-2016)

\begin{abstract}
ABSTRAK
Budidaya ikan lele (Clarias sp.) menghasilkan limbah organik yang dapat menyebabkan penurunan kualitas air. Penelitian bertujuan menganalisis kemampuan kangkung (Ipomoea aquatica) dan pakcoy (Brassica rapa chinenesis) sebagai agen fitoremediator limbah dalam sistem resirkulasi. Penelitian dilakukan dalam laboratorium menggunakan rancangan acak lengkap in time dengan tiga perlakuan, tiga ulangan, selama 35 hari pengamatan. Secara umum parameter kualitas air yang diamati (suhu, $\mathrm{pH}$, oksigen terlarut, amonia total, amonia bebas, ammonium, nitrat, dan ortofosfat) menunjang bagi kehidupan ikan lele, kangkung, dan pakcoy. Suhu air selama pengamatan $\left(27-30^{\circ} \mathrm{C}\right)$ berpengaruh terhadap pertumbuhan pakcoy, dimana pakcoy merupakan tanaman introduksi dari subtropis yang bersuhu dingin $\left(18-22{ }^{\circ} \mathrm{C}\right)$. Persentasi penurunan amonium pada perlakuan kangkung $(78,42 \%)$ dan pakcoy $(52,16 \%)$. Penyerapan amonium secara langsung melalui akar sebagai pupuk alami pada kangkung lebih optimal bila dibandingkan dengan pakcoy. Persentase penurunan amonia bebas menunjukkan perbedaan pada perlakuan kontrol, kangkung, dan pakcoy berturut-turut adalah $89,16 \%, 93,62 \%$, dan 96,62\%. Perlakuan kangkung lebih efektif dalam meningkatkan tingkat kelangsungan hidup dan laju konversi pakan ikan lele.
\end{abstract}

Kata kunci: fitoremediasi, ikan lele (Clarias sp.), kangkung (Ipomoea aqatica), limbah, pakcoy (Brasssica rapa chinensis)

\begin{abstract}
Catfish (Clarias sp.) culture produces organic waste that can cause a decrease in water quality of the culture media. The study aimed to analyze the ability of water spinach (Ipomoea aquatica) and pakcoy (Brassica rapa chinenesis) as agents for waste phytoremediation in the recirculation system. The study was conducted in the laboratory using a completely randomized design in time with three treatments, three replications, during the 35 days of observation. The observed water quality parameters (temperature, $\mathrm{pH}$, dissolved oxygen, total ammonia, free ammonia, ammonium, nitrate and orthophosphate) support for the life of catfish, water spinach, and pakcoy. The water temperature during the observation $\left(27-30^{\circ} \mathrm{C}\right)$ affected pakcoy growth, where pakcoy is a subtropical plant of cold temperature $\left(18-22^{\circ} \mathrm{C}\right)$. Percentage decrease of ammonium in water spinach treatment $(78.42 \%)$ and pakcoy treatment (52.16\%). Ammonium absorption directly through the roots as a natural fertilizer in water spinach is more optimal when compared with pakcoy. The percentage decrease of free ammonia indicated difference in the control, water spinach, and pakcoy namely $89.16 \%, 93.62 \%$ and $96.62 \%$, respectively. Water spinach treatment was more effective in improving the survival rate and feed conversion rate of catfish .
\end{abstract}

\footnotetext{
${ }^{1)}$ Pusat Penelitian Lingkungan Hidup (PPLH), IPB

2) Program Diploma Aquaculture, IPB

${ }^{3)}$ Departemen Manajemen Sumberdaya Perairan,Fakultas Perikanan dan Ilmu Kelautan, IPB
} 


\section{PENDAHULUAN}

Ikan lele (Clarias sp.) merupakan salah satu jenis ikan yang memiliki nilai ekonomis, mudah dipelihara dan dapat tumbuh dengan cepat. Potensi tersebut mendorong minat masyarakat untuk meningkatkan produksi melalui budidaya secara intensif[1]. Kegiatan budidaya menghasilkan limbah padat dan limbah cair yang berasal dari feses dan sisa pakan ikan [2]. Akumulasi limbah tersebut dapat menyebabkan penurunan kualitas air yang berpengaruh terhadap proses fisiologis, tingkah laku, pertumbuhan, dan mortalitas ikan [3]. Oleh karena itu, diperlukan pengelolaan terhadap kualitas air media pemeliharaan ikan.

Pengelolaan kualitas air secara konvensional dapat dilakukan dengan pergantian air budidaya secara berkala, namun kurang efektif karena membutuhkan air yang cukup banyak dan biaya yang mahal [4]. Salah satu upaya pengelolaan untuk meningkatkan kualitas air dan mengoptimalkan pemanfaatan air budidaya adalah dengan fitoremediasi secara resirkulasi [5]. Air limbah budidaya yang mengandung bahan organik akan dimanfaatkan oleh tanaman sebagai nutrien untuk pertumbuhan [6]. Prinsip sistem resirkulasi adalah penggunaan kembali air yang telah dikeluarkan dari kegiatan budidaya [7]. Keuntungan sistem resirkulasi, yaitu dapat meminimalisir penggunaan air, buffer $\mathrm{pH}$, dan mereduksi bahan organik seperti amonia, nitrit, dan buffer $\mathrm{pH}[8]$.

Fitoremediasi merupakan penggunaan tumbuhan untuk menurunkan, mengekstrak atau menghilangkan senyawa organik dan anorganik dari limbah [9]. Keunggulan fitoremediasi dibandingkan dengan teknologi pengolahan limbah lain adalah proses secara alami, biaya lebih rendah, reduksi bahan organik secara permanen, terjadi hubungan sinergi antara tanaman, organisme, dan lingkungan serta tidak memerlukan teknologi tinggi [10]. Tanaman air yang sering digunakan sebagai fitoremediator limbah adalah selada air (Lactuca sativa L), enceng gondok (Eichornia crassipes), kayu apu (Pistia stratiotes), kiambang (Salvinia molesta), dan lain-lain.

Tanaman yang digunakan pada penelitian ini adalah kangkung (Ipomoea aquatica) dan pakcoy (Brassica rapa chinensis). Kangkung dapat memanfaatkan nutrien seperti nitrogen dan fosfor untuk pertumbuhan [11]. Penelitian menggunakan kangkung sebagai agen fitoremediator limbah diantaranya telah dilakukan oleh Effendi et al. ${ }^{[11]}$, Lestari ${ }^{[12]}$, dan Indah et al. ${ }^{[13]}$. Selain kangkung, pakcoy juga merupakan tanaman yang dapat menyerap bahan organik berdasarkan penelitian yang dilakukan oleh Andreeilee et al. ${ }^{[14]}$. Menurut Wibowo dan Asriyanti ${ }^{[15]}$, pakcoy merupakan tanaman yang mudah dibudidayakan dan tahan terhadap kadar air tinggi dan tidak bergantung pada musim. Selain dapat digunakan sebagai agen fitoremediator limbah, kangkung (Ipomoea aquatica) dan pakcoy (Brassica rapa chinensis) memiliki nilai ekonomi, yaitu juga dapat dipanen dan dikonsumsi.

\section{BAHAN DAN METODE}

\section{Rancangan Percobaan}

Rancangan percobaan pada penelitian adalah rancangan acak lengkap in time (RAL in time). Perlakuan yang digunakan ada tiga, yaitu kontrol, kangkung (Ipomoea aquatica), dan pakcoy (Brassica rapa chinensis) dengan masing-masing tiga kali ulangan. Pengamatan enam kali dengan selang waktu satu minggu selama 35 hari. 
Akuarium pemeliharaan ikan lele berukuran $80 \mathrm{~cm}$ x $40 \mathrm{~cm}$ x $30 \mathrm{~cm}$ sebanyak tiga unit setiap perlakuan. Setiap akuarium dilengkapi dengan talang air berukuran $100 \mathrm{~cm}$ x 15 $\mathrm{cm}$. Talang air digunakan untuk menanam kangkung dan pakcoy serta mengalirkan air ke tandon berupa drum berdiameter $60 \mathrm{~cm}$. Cara kerja sistem resirkulasi pada penelitian sebagai berikut. Air limbah dari akuarium pemeliharaan ikan dialirkan secara gravitasi melalui pipa ke talang air yang telah ditanami kangkung (Ipomoea aquatica) dan pakcoy (Brassica rapa chinensis). Air yang telah diolah dialirkan kembali ke akuarium menggunakan pompa dan seterusnya (Gambar 1).

Ikan lele (Clarias sp.) yang digunakan dalam penelitian berasal dari petani di Cibereum dan diaklimatisasi selama satu minggu di akuarium (Lampiran 4). Sebanyak 220 ekor diberikan pada setiap akuarium untuk setiap perlakuan dengan ukuran 4-5 cm (Lampiran 4). Penyemaian kangkung dan pakcoy dilakukan selama satu minggu pada media arang sekam. Tanaman ditanam di talang air menggunakan media rockwool dengan bantuan styrofoam agar daun tanaman tidak terendam air (Lampiran 3). Kangkung ditanam sebanyak 16 rumpun (delapan pot) per perlakuan dengan jarak tanam $10 \mathrm{~cm}$ [16]. Pakcoy ditanam lima rumpun (lima pot) per perlakuan dengan jarak tanam $20 \mathrm{~cm}$ [17]. Tanaman diberi nutrisi Murashige dan Skoog (MS) sebanyak satu ml per tanaman per hari. Komposisi nutrisi disajikan pada Lampiran 5. Pemberian nutrisi tersebut diharapkan dapat meningkatkan pertumbuhan kangkung dan pakcoy.

\section{Analisis Data}

Pengukuran kualitas air dilakukan pada awal sebelum perlakuan dan diukur seminggu sekali selama pemeliharaan. Paramater kualitas air yang diamati adalah suhu (thermometer), pH (pH meter), DO (modifikasi Winkler), nitrat (brucine), amonia total (phenate), dan ortofosfat (molibdate) [18].

Nilai amonium $\left(\mathrm{NH}_{4}^{+}\right)$pada penelitian ini diperoleh dari nilai amonia total (TAN) dikurangi amonia bebas $\left(\mathrm{NH}_{3}\right)$. Ammonia bebas ditentukan dengan formula berikut, ammonia $\left(\mathrm{NH}_{3}\right)=\mathrm{TAN} /[1+\operatorname{antilog}(\mathrm{pKa}-$ $\mathrm{pH})$ ] [19]. Nilai pKa didasarkan pada temperatur $5-30{ }^{\circ} \mathrm{C}$ dan $\mathrm{pH}$.

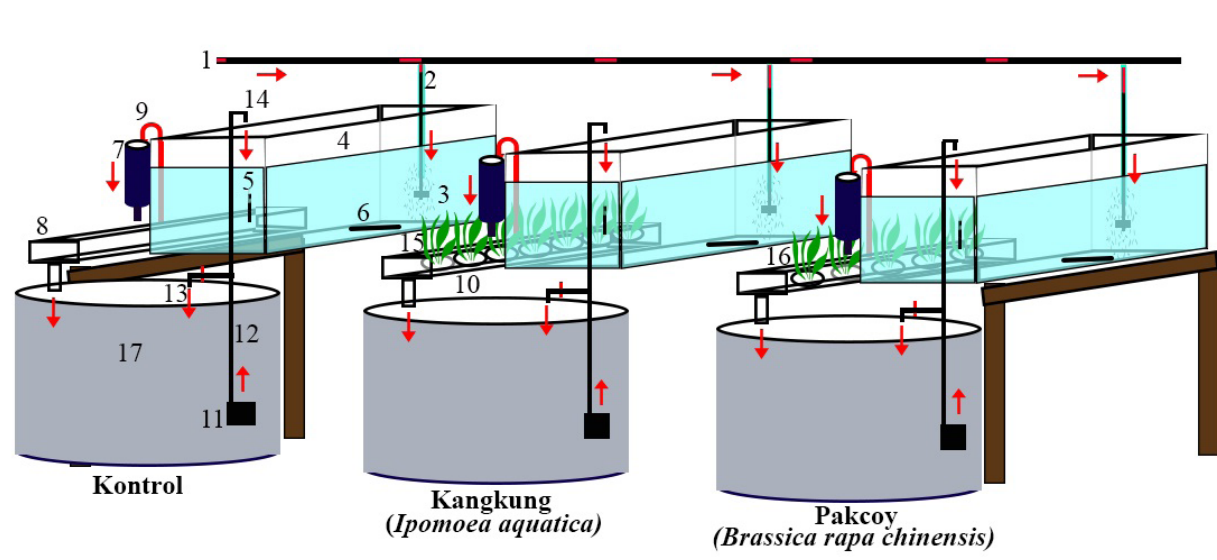

Keterangan gambar:
1 Pipa aerasi
2 Selang aerasi
3 Batu aerasi
4 Akuarium
5 Termometer
6 Water heater
7 Bejana berhubungan
8 Talang air
9 Outlet air dari akuarium
10 Styrofoam dan rockwool
11 Water pump
12 Pipa saluran water pump
13 Kran pengatur debit
14 Pipa inlet akuarium
15 Kangkung (Ipomoea aquatica)
16 Pakcoy (Brassica rapa chinensis)
17 Tandon air

Gambar 1. Rancangan akuarium resirkulasi akuarium kontrol, kangkung (Ipomoea aquatica), dan pakcoy (Brassica rapa chinensis) 


\begin{tabular}{cccccccccccc}
\hline Suhu $\left({ }^{\circ} \mathrm{C}\right)$ & 15 & 20 & 24 & 25 & 26 & 27 & 28 & 29 & 30 & 31 & 32 \\
\hline pKa & 9,56 & 9,40 & 9,27 & 9,24 & 9,21 & 9,18 & 9,15 & 9,12 & 9,09 & 9,06 & 9,03 \\
\hline
\end{tabular}

Perubahan kualitas air karena perlakukan ditentukan dengan persamaan berikut \% perubahan $=[(a-b) / a] \times 100 \%$, a adalah konsentrasi kualitas air pada watu t0, b adalah konsentrasi kualitas air pada akhir penelitian. Panjang dan bobot ikan diukur satu minggu sekali sebanyak $30 \%$ dari populasi ikan di akuarium. Panjang ikan diukur dari ujung ekor hingga ujung kepala menggunakan penggaris, disamping itu bobot diukur menggunakan timbangan digital.

Tingkat kelangsungan hidup (SR\%), rasion konversi makanan (FCR), pertambahan berat (gr), pertambahan panjang $(\mathrm{cm})$ dan laju pertumbuhan spesifik (\%) ditentukan denan persamaan berikut: (1) SR \% $=\left(\mathrm{N}_{\mathrm{t}} / \mathrm{N}_{0}\right) \times 100$ [20]; (2) $\mathrm{FCR}=\sum \mathrm{F} /\left(\mathrm{B}_{\mathrm{t}}+\mathrm{D}-\mathrm{B}_{0}\right)[21]$; (3) Wa $=\mathrm{W}_{\mathrm{t}}-\mathrm{W}_{0}$; (4) $\mathrm{La}=\mathrm{L}_{\mathrm{t}}-\mathrm{L}_{0} ;$ (5) $\mathrm{SGR} \%=100 \mathrm{x}$ $\left(\ln \mathrm{W}_{\mathrm{t}}-\ln \mathrm{W}_{0}\right) / \mathrm{t}$ [22], dimana $\mathrm{N}_{\mathrm{t}} \mathrm{N}_{0}, \mathrm{~F}, \mathrm{~B}_{\mathrm{t}}, \mathrm{D}$, $\mathrm{B}_{0}, \mathrm{~W}_{0}, \mathrm{~W}_{\mathrm{t}}, \mathrm{L}_{\mathrm{t}} \mathrm{L}_{0}$ t adalah berturut-turut jumlah ikan pada akhir penelitian, jumlah ikan diawal penelitian, jumlah pakan yang diberikan, berat akhir ikan, berat awal ikan, panjang akhir, panjang awal, berat basah awal, berat basah akhir, dan jumlah hari penelitian.

Peningkatan biomassa tanaman air diindikasikan oleh doubling time, yaitu waktu yang dibutuhkan untuk menggandakan biomassa. Doubling time dapat dihitung dengan pendekatan pertumbuhan relatif yang ditentukan dengan rumus berikut $R G R=\left(\ln X_{t}\right.$ - $\ln \mathrm{X}_{0}$ )/ t,dimana $\mathrm{X}_{\mathrm{t}}$ dan $\mathrm{X}_{0}$ adalah berat akhir dan berat awal pada waktu t (hari) [23].

\section{Hasil dan Pembahasan}

\section{Suhu $\left({ }^{0} \mathrm{C}\right)$}

Suhu merupakan faktor yang berpengaruh terhadap proses fitoremediasi, pertumbuhan ikan dan tanaman serta proses dekomposisi bahan organik. Suhu air selama pengamatan relatif konstan, yaitu berkisar $27-30{ }^{\circ} \mathrm{C}$. Menurut Boyd dan Lichtkoppler ${ }^{[24]}$, suhu optimum untuk pertumbuhan ikan adalah 25-32 ${ }^{\circ} \mathrm{C}$. Ikan merupakan hewan berdarah dingin sehingga suhu tubuh ikan akan berubah sesuai dengan suhu lingkungan. Perubahan suhu tersebut mempengaruhi metabolisme, fisiologi, dan pertumbuhan ikan [25]. Suhu optimum untuk pertumbuhan kangkung berkisar $25-30{ }^{\circ} \mathrm{C}$ [13]. Sebaliknya pakcoy tidak dapat tumbuh dengan baik pada kisaran tersebut. Hal ini karena pakcoy merupakan tanaman introduksi dari subtropis yang bersuhu dingin. Kisaran suhu optimum untuk pertumbuhan pakcoy adalah $18-22{ }^{\circ} \mathrm{C}$ [26].

\section{pH (Derajat Keasaman)}

Nilai $\mathrm{pH}$ menggambarkan ion hidrogen dalam suatu perairan. Nilai $\mathrm{pH}$ air selama pengamatan berkisar antara 6-8. Ikan dan biota lain di air dapat tumbuh dengan baik pada $\mathrm{pH}$ 6-9 [27]. Sebaliknya tanaman dapat tumbuh dengan baik pada $\mathrm{pH}$ 5,5-7 karena proses penyerapan unsur hara dari air dapat berlangsung dengan baik [12]. Berdasarkan pengamatan diduga pertumbuhan tanaman lambat karena $\mathrm{pH}$ lingkungan lebih tinggi dari $\mathrm{pH}$ optimum untuk pertumbuhan tanaman. 
Selain berpengaruh terhadap pertumbuhan ikan dan tanaman, $\mathrm{pH}$ juga mempengaruhi proses dekomposisi bahan organik di air. Menurut Tarre dan Green ${ }^{[28]}$, proses dekomposisi bahan organik akan berlangsung baik pada $\mathrm{pH}$ 7-8 karena bakteri nitrifikasi sebagai dekomposer dapat tumbuh dengan baik.

\section{Oksigen Terlarut (DO)}

Proses penyerapan bahan organik oleh tanaman terjadi melalui akar. Akar tanaman membutuhkan oksigen yang cukup untuk respirasi sehingga penyerapan unsur hara dapat optimal [29]. Konsentrasi oksigen yang baik untuk respirasi akar tanaman adalah 2,5 mg L ${ }^{-1}$, pada konsentrasi oksigen dibawah $0,16 \mathrm{mg} \mathrm{L}^{-1}$ akan menyebabkan akar dan daun tanaman layu [5].

Selama pengamatan, konsentrasi oksigen terlarut mengalami penurunan. Konsentrasi oksigen rata-rata perlakuan kontrol, kangkung dan pakcoy berkisar $2.95 \mathrm{mg} \mathrm{L}^{-1}, 3.19 \mathrm{mg} \mathrm{L}^{-1}$ dan $2.75 \mathrm{mg} \mathrm{L}^{-1}$. Berdasarkan pengamatan konsentrasi oksigen masih dalam rentang cukup untuk pertumbuhan tanaman dan ikan. Konsentrasi oksigen terlarut optimum untuk pertumbuhan ikan lele adalah $>3 \mathrm{mg} \mathrm{L}^{-1}[30$,
5, 31]. Ikan lele masih mampu hidup pada konsentrasi oksigen $<3 \mathrm{mg} \mathrm{L}^{-1}$ karena memiliki alat pernafasan tambahan untuk mengambil oksigen dari udara [32].

\section{Amonia total $\left(\mathrm{NH}_{3}-\mathrm{N}\right)$}

Amonia merupakan hasil katabolisme protein dan dekomposisi bahan organik seperti sisa pakan, feses, dan plankton yang mati oleh bakteri pengurai [33]. Hasil pengukuran amonia selama penelitian disajikan pada

\section{Tabel 1.}

Nitrogen di air terdiri atas beberapa bentuk diantaranya amonia total, nitrogen bebas, amonium, nitrit, dan nitrat. Amonia yang ada di air merupakan amonia total yang terdiri atas $\mathrm{NH}_{3}$ dan $\mathrm{NH}_{4}^{+}$[6]. Kesetimbangan amonia bebas dan amonium dipengaruhi oleh suhu dan $\mathrm{pH}$. Amonia bebas $\left(\mathrm{NH}_{3}\right)$ tidak terionisasi dan bersifat toksik terhadap biota akuatik, sedangkan $\mathrm{NH}_{4}^{+}$dapat digunakan langsung oleh tumbuhan sebagai sumber nutrien [34]. Toksisitas amonia bebas meningkat dengan menurunnya oksigen dan peningkatan suhu dan $\mathrm{pH}$. Pada $\mathrm{pH} 7$, sebagian besar amonia total akan terionisasi menjadi amonium dan pada $\mathrm{pH}>8,75,30 \%$ amonia total akan

Tabel 1. Nilai amonia total setiap pengamatan pada perlakuan kontrol, kangkung (Ipomoea aquatica) dan pakcoy (Brassica rapa chinensis).

\begin{tabular}{cccc}
\hline \multirow{2}{*}{ Hari ke- } & \multicolumn{3}{c}{ Amonia Total $\left(\mathrm{mg} \mathrm{L}^{-1}\right)$} \\
\cline { 2 - 4 } & Kontrol $^{\mathrm{a}}$ & Kangkung $^{\mathrm{a}}$ & Pakcoy $^{\mathrm{a}}$ \\
\hline $0^{\mathrm{a}}$ & 3,09 & 2,84 & 3,94 \\
$7^{\mathrm{d}}$ & 0,26 & 0,09 & 0,10 \\
$14^{\mathrm{d}}$ & 0,44 & 0,09 & 0,06 \\
$21^{\mathrm{bc}}$ & 0,51 & 0,86 & 1,62 \\
$28^{\mathrm{b}}$ & 2,13 & 1,18 & 0,99 \\
$35^{\mathrm{cd}}$ & 0,45 & 0,32 & 0,32 \\
Rata-rata \pm SD & $1,15 \pm 1,17$ & $0,90 \pm 1,05$ & $1,17 \pm 1,48$ \\
\hline
\end{tabular}

Huruf superscript yang berbeda pada kolom dan baris yang sama menunjukkan hasil berbeda nyata pada taraf uji 5\% (uji selang berganda Duncan) 
berubah menjadi amonia bebas yang lebih toksik [35].

Reduksi amonia melalui proses nitrifikasi terjadi dengan bantuan bakteri Nitrobacter. Nitrifikasi merupakan proses oksidasi amonia menjadi amonium, nitrit, dan nitrat yang berlangsung pada kondisi aerob [36, 37]. Proses nitrifikasi dipengaruhi oleh beberapa faktor diantaranya substrat dan oksigen terlarut, bahan organik, suhu, $\mathrm{pH}$, alkalinitas, salinitas, dan turbulensi [36, 33]. Nitrifikasi akan berjalan dengan baik pada oksigen terlarut $>1 \mathrm{mg} \mathrm{L}^{-1}$, suhu $25-35{ }^{\circ} \mathrm{C}$ dan $\mathrm{pH}$ 7,5-8,6, karena pada kisaran tersebut bakteri nitrifikasi dapat tumbuh dengan baik $[36,33]$. Selama pengamatan, oksigen terlarut berkisar antara 1,31-5,21 $\mathrm{mg} \mathrm{L}^{-1}$, suhu $27-30{ }^{\circ} \mathrm{C}$ dan $\mathrm{pH}$ 6-8, sehingga proses nitrifikasi dapat berjalan dengan baik.

Selama pengamatan, konsentrasi amonia total berfluktuasi. Persentase penurunan amonia pada perlakuan kontrol, kangkung, dan pakcoy adalah $78,89 \%, 72,81 \%$ dan $67,91 \%$. Hasil uji statistik menunjukkan penurunan amonia total tidak berbeda nyata antar perlakuan $(p>0,05)$ tetapi berbeda nyata antar waktu pengamatan $(\mathrm{p}<0,05)$.

\section{Amonia bebas $\left(\mathrm{NH}_{3}\right)$}

Amnonia bebas merupakan bentuk nitrogen yang tidak terionisasi dan toksik terhadap organisme akuatik [34]. Selama pengamatan, konsentrasi amonia berfluktuasi. Penurunan konsentrasi tertinggi terjadi pada hari ke-7. Hasil pengukuran amonia bebas disajikan dalam Tabel 2.

Persentase penurunan amonia bebas pada perlakuan kontrol, kangkung, dan pakcoy adalah $89,16 \%, 93,62 \%$ dan 96,62\%. Konsentrasi amonia optimum untuk pertumbuhan ikan lele adalah $<0,025 \mathrm{mg} \mathrm{L}^{-1}$ [25].

Konsentrasi amonia $>0,3 \mathrm{mg} \mathrm{L}^{-1}$ akan menyebabkan stres, nafsu makan menurun, dan kematian ikan [38]. Berdasarkan uji statistik tanaman kangkung dan pakcoy sebagai fitoremediator tidak memberikan pengaruh yang berbeda $(p>0,05)$, namun waktu pengamatan memberikan pengaruh berbeda $(p<0,05)$ terhadap penurunan amonia.

\section{Amonium $\left(\mathrm{NH}_{4}^{+}\right)$}

Amonium merupakan bentuk nitrogen yang dapat dimanfaatkan secara langsung oleh tumbuhan dan alga. Amonium dalam jumlah

Tabel 2. Nilai amonia setiap pengamatan pada perlakuan kontrol, kangkung (Ipomoea aquatica) dan pakcoy (Brassica rapa chinensis)

\begin{tabular}{cccc}
\hline \multirow{2}{*}{ Hari ke- } & \multicolumn{3}{c}{ Amonia $\left(\mathrm{NH}_{3}-\mathrm{N}\right)$} \\
\cline { 2 - 4 } & Kontrol & Kangkung & Pakcoy \\
\hline 0 & 0,1793 & 0,1651 & 0,2934 \\
7 & 0,0194 & 0,0105 & 0,0093 \\
24 & 0,0040 & 0,0008 & 0,0005 \\
21 & 0,0013 & 0,0060 & 0,0057 \\
28 & 0,0090 & 0,0119 & 0,0052 \\
35 & 0,0012 & 0,0034 & 0,0030 \\
Rata-rata \pm SD & $0,0357 \pm 0,0707$ & $0,0330 \pm 0,0649$ & $0,0528 \pm 0,1179$ \\
\hline
\end{tabular}

Huruf superscript yang berbeda pada kolom dan baris yang sama menunjukkan hasil berbeda nyata pada taraf uji 5\% (uji selang berganda Duncan) 
besar di air tidak menyebabkan toksik bagi organisme akuatik. Selama pengamatan, konsentrasi amonium mengalami penurunan. Persentase penurunan amonium pada perlakuan kontrol, kangkung, dan pakcoy adalah $70,01 \%, 78,42 \%$, dan $52,16 \%$.

Amonium merupakan bentuk nitrogen yang dapat dimanfaatkan langsung oleh tanaman melalui proses fitoremediasi [39, 40]. Amonium diserap oleh tanaman melalui akar sebagai pupuk alami untuk pertumbuhan [41], sehingga tidak bersifat toksik bagi organisme akuatik. Penurunan konsentrasi amonium pada pengamatan mengindikasikan tanaman dan alga memanfaatkan amonium yang terbentuk di air. Berdasarkan uji statistik tanaman kangkung dan pakcoy sebagai fitoremediator tidak memberikan pengaruh yang berbeda $(p>0,05)$, namun waktu pengamatan memberikan pengaruh berbeda $(p<0,05)$ terhadap penurunan amonium.

\section{Nitrat $\left(\mathrm{N}-\mathrm{NO}_{3}\right)$}

Nitrat merupakan bentuk utama dari senyawa nitrogen di perairan dan merupakan nutrien bagi pertumbuhan tanaman dan alga di air. Nitrat berasal dari oksidasi amonia menjadi nitrit dan nitrat oleh bakteri Nitrobacter [34]. Hasil pengukuran nitrat selama penelitian disajikan pada Tabel 3. Konsentrasi nitrat selama pengamatan masih optimum untuk pertumbuhan ikan lele. Menurut Bhatnagar et al. ${ }^{[25]}$, ikan lele dapat tumbuh dengan baik pada konsentrasi nitrat $<20 \mathrm{mg} \mathrm{L}^{-1}$.

Konsentrasi nitrat cenderung meningkat dari setiap pengamatan dan tertinggi pada perlakuan kangkung. Persentase peningkatan konsentrasi nitrat pada perlakuan kontrol, kangkung, dan pakcoy adalah 7,14\%, 11,63\%, dan 7,14\%. Konsentrasi nitrat cenderung meningkat dari setiap pengamatan. Menurut Effendi et al. ${ }^{[11]}$ tanaman dapat mereduksi amonium lebih cepat dibandingkan nitrat. Peningkatan konsentrasi nitrat selama pengamatan mengindikasikan terjadi proses nitrifikasi amonia oleh bakteri. Namun nitrat yang dihasilkan tidak dimanfaatkan seluruhnya oleh tanaman sehingga terjadi akumulasi di air.

Berdasarkan uji statistik menunjukkan perlakuan kontrol, kangkung dan pakcoy serta perbedaan waktu pengamatan tidak berpengaruh nyata $(p>0,05)$ terhadap peningkatan nitrat .

Tabel 3.Nilai nitrat setiap pengamatan pada perlakuan kontrol, kangkung (Ipomoea aquatica) dan pakcoy (Brassica rapa chinensis).

\begin{tabular}{cccc}
\hline \multirow{2}{*}{ Hari ke- } & \multicolumn{3}{c}{${\text { Nitrat }\left(\mathrm{mg} \mathrm{L}^{-1}\right)}$} \\
\cline { 2 - 4 } & Kontrol $^{\mathrm{a}}$ & Kangkung $^{\mathrm{a}}$ & Pakcoy $^{\mathrm{a}}$ \\
\hline $0^{\mathrm{a}}$ & 2,50 & 2,63 & 3,03 \\
$7^{\mathrm{a}}$ & 4,70 & 3,40 & 3,27 \\
$14^{\mathrm{a}}$ & 3,23 & 3,80 & 3,43 \\
$21^{\mathrm{a}}$ & 3,47 & 4,10 & 3,77 \\
$28^{\mathrm{a}}$ & 3,73 & 4,30 & 3,50 \\
$35^{\text {a }}$ & 4,00 & 4,80 & 3,73 \\
Rata-rata \pm SD & $3,61 \pm 0,74$ & $3,84 \pm 0,76$ & $3,46 \pm 0,28$ \\
\hline
\end{tabular}

Huruf superscript yang berbeda pada kolom dan baris yang sama menunjukkan hasil berbeda nyata pada taraf uji 5\% (uji selang berganda Duncan) 


\section{Ortofosfat (P-PO $)$}

Ortofosfat merupakan senyawa anorganik terlarut yang dimanfaatkan oleh tumbuhan dan ikan sebagai senyawa esensial untuk pertumbuhan [34]. Hasil pengukuran ortofosfat selama penelitian disajikan pada Tabel 4. Konsentrasi orthofosfat cenderung berfluktuasi setiap pengamatan. Konsentrasi orthofosfat yang optimum untuk pertumbuhan ikan lele berkisar $0,05-0,07 \mathrm{mg} \mathrm{L}^{-1}$ [25]. Pakan ikan mengandung nitrogen dan fosfor, namun tidak semua dikonversi oleh ikan untuk pertumbuhan [38]. Menurut Crab et al. ${ }^{[36]}$, sebanyak 75\% kandungan $\mathrm{N}$ dan $\mathrm{P}$ pakan diekskresikan dan terakumulasi di dasar.

Konsentrasi orthofosfat selama pengamatan cenderung berfluktuasi. Konsentrasi optimum untuk pertumbuhan ikan lele berkisar 0,05$0,07 \mathrm{mg} \mathrm{L}^{-1}$ [25]. Fosfor di air berasal dari sisa pakan dan ekskresi ikan [36]. Orthoposfat $\left(\mathrm{PO}_{4}^{3-}\right)$ merupakan bentuk anorganik dari fosfor yang dapat dimanfaatkan oleh tumbuhan dan mikroorganisme [38, 11]. Orthofosfat merupakan senyawa anorganik yang dapat dimanfaatkan secara langsung oleh kangkung dan pakcoy untuk pertumbuhan. Konsentrasi orthofosfat dipengaruhi oleh suhu dan $\mathrm{pH}$.
Konsentrasi orthofosfat akan meningkat dengan peningkatan suhu dan penurunan $\mathrm{pH}$ [34]. Pemanfaatan kangkung dan pakcoy sebagai fitoremediator serta perbedaaan waktu pengamatan memberikan pengaruh nyata $(p<0,05)$ terhadap penurunan orthofosfat di air. Persentase penurunan konsentrasi orthofosfat pada perlakuan kontrol, kangkung dan pakcoy adalah $60,46 \%, 57,02 \%$, dan $28,16 \%$.

\section{Panjang, Bobot, dan Pertumbuhan Tingkat Kelangsungan Hidup dan Laju Konversi pakan Ikan Lele (Clarias sp.)}

Bobot rata-rata untuk semua perlakuan berkisar antara 1.45-1.56 gr dan bobot akhir rata-rata berkisar antara 8.10-8.65gr (Tabel 5). Panjang rata-rata semua perlakuan berkisar antara 5.29$5.45 \mathrm{~cm}$ dan panjang rata-rata berkisar antara 9.73-10.03 cm. Laju konversi pakan ikan lele (Clarias sp.) perlakuan kangkung lebih baik dari perlakuan kontrol dan pakcoy. Hal ini sesuai dengan pertumbuhan bobot mutlak dan panjang mutlak ikan pada perlakuan kontrol lebih tinggi dari perlakuan kangkung dan pakcoy (Tabel 5). Pertumbuhan bobot mutlak dan panjang mutlak ikan lele tidak berbeda $(\mathrm{p}>0.05)$ antar perlakuan dan pengamatan.

Tabel 4. Nilai orthoposfat setiap pengamatan pada perlakuan kontrol, kangkung (Ipomoea aquatica) dan pakcoy (Brassica rapa chinensis).

\begin{tabular}{cccc}
\hline \multirow{2}{*}{ Hari ke- } & \multicolumn{3}{c}{ Orthoposfat $\left(\mathrm{mg} \mathrm{L}^{-1}\right)$} \\
\cline { 2 - 4 } & Kontrol $^{\mathrm{ab}}$ & Kangkung $^{\mathrm{a}}$ & Pakcoy $^{\mathrm{b}}$ \\
\hline $0^{\mathrm{c}}$ & 0,31 & 0,21 & 0,14 \\
$7^{\mathrm{c}}$ & 0,12 & 0,35 & 0,23 \\
$14^{\mathrm{c}}$ & 0,25 & 0,37 & 1,02 \\
$21^{\mathrm{b}}$ & 0,86 & 0,71 & 1,81 \\
$28^{\mathrm{a}}$ & 2,34 & 1,29 & 1,65 \\
$35^{\mathrm{bc}}$ & 0,71 & 0,55 & 1,19 \\
Rata-rata $\pm S D$ & $0,77 \pm 0,82$ & $0,58 \pm 0,39$ & $1,01 \pm 0,70$ \\
\hline
\end{tabular}

Huruf superscript yang berbeda pada kolom dan baris yang sama menunjukkan hasil berbeda nyata pada taraf uji 5\% (uji selang berganda Duncan). 


\begin{tabular}{llll}
\hline Parameter & Kontrol & Kangkung & Pakcoy \\
\hline a. Awal & & & \\
Bobot rata-rata $(g r \pm S D)$ & $1.45 \pm 0.22$ & $1.56 \pm 0.08$ & $1.44 \pm 0.19$ \\
Panjang rata-rata $(\mathrm{cm} \pm \mathrm{SD})$ & $5.34 \pm 0.20$ & $5.45 \pm 0.15$ & $5.29 \pm 0.18$ \\
b. Akhir & & & \\
Waktu pemeliharaan (hari) & 35 & 35 & 35 \\
Bobot rata-rata (gr $\pm S D)$ & $8.65 \pm 0.89$ & $8.61 \pm 1.47$ & $8.10 \pm 2.56$ \\
Panjang rata-rata (cm $\pm S D)$ & $10.03 \pm 0.32$ & $9.86 \pm 0.73$ & $9.73 \pm 1.00$ \\
Tingkat kelangsungan hidup (\%) & $89,85 \pm 9,77$ & $94,24 \pm 1,84$ & $89,85 \pm 12,87$ \\
Laju konversi pakan & $0,85 \pm 0,06$ & $0,82 \pm 0,02$ & $1,08 \pm 0,49$ \\
c. Pertumbuhan & & & \\
Bobot mutlak (gr) & $2,98 \pm 2,88^{\mathrm{a}}$ & $2,92 \pm 2,73^{\mathrm{a}}$ & $2,63 \pm 2,64^{\mathrm{a}}$ \\
Panjang mutlak (cm) & $2,20 \pm 2,89^{\mathrm{a}}$ & $2,09 \pm 1,82^{\mathrm{a}}$ & $2,06 \pm 1,79^{\mathrm{a}}$ \\
SGR (\%/hari) & $4,42 \pm 2,26^{\mathrm{a}}$ & $4,09 \pm 2,23^{\mathrm{a}}$ & $3,81 \pm 2,05^{\mathrm{a}}$ \\
\hline
\end{tabular}

Tabel 5.Panjang, Bobot, dan Pertumbuhan Tingkat Kelangsungan Hidup dan Laju Konversi pakan Ikan Lele (Clarias sp.).

Laju pertumbuhan spesifik (SGR) pada perlakuan kontrol lebih tinggi dibandingkan dengan perlakuan kangkung dan pakcoy (Tabel 5). Laju pertumbuhan spesifik ikan berkisar antara 3.81-4.42, lebih besar dibandingkan dengan penelitian yang dilakukan oleh Jimoh et al. ${ }^{[42]}$ yaitu sebesar $2.59-2.70 \%$ /hari dan penelitian yang dilakukan oleh Dasuki et al. ${ }^{[43]}$ 3.14-3.33\%/hari. Laju pertumbuhan spesifik ikan lele tidak berbeda $(\mathrm{p}>0.05)$ antar perlakuan dan pengamatan.

Tingkat kelangsungan hidup ikan lele dengan perlakuan kangkung sebagai fitoremediator lebih tinggi dari perlakuan pakcoy dan kontrol (Tabel 5). Tingkat kelangsungan hidup ikan pada pengamatan lebih rendah dari penelitian yang dilakukan oleh Dasuki et al. ${ }^{[43]}$, yaitu 99.5-99.84\%, namun lebih tinggi dari penelitian Jimoh et al. ${ }^{[42]}$ yaitu $77.78-86.68 \%$. Kelangsungan hidup ikan dipengaruhi oleh berbagai faktor diantaranya kualitas air (oksigen terlarut, amonia, suhu, $\mathrm{pH}$ ), pakan, umur ikan, lingkungan, dan kondisi kesehatan ikan $[32,44]$.
Korelasi parameter kualitas air dan pertumbuhan ikan disajikan pada Tabel 6. Oksigen terlarut berkorelasi erat $(\mathrm{p}<0,01)$ dengan tingkat kelangsungan hidup ikan, bobot mutlak, dan panjang mutlak. Korelasi tersebut menunjukkan bahwa oksigen mempengaruhi laju konversi pakan, metabolisme, pertumbuhan, dan tingkat kelangsungan hidup ikan. Tingkat kelangsungan hidup ikan berkorelasi erat $(p<0,01)$ dengan pertumbuhan bobot mutlak dan panjang mutlak. Korelasi tersebut menunjukkan bahwa jumlah ikan di akuarium mempengaruhi pertumbuhan ikan. Hal ini diduga karena ada pengaruh dari persaingan makanan, sehingga mempengaruhi pertumbuhan ikan. Panjang mutlak memiliki korelasi erat $(p<0,01)$ dengan bobot mutlak ikan. Hal ini menunjukkan pertumbuhan panjang mutlak mempengaruhi pertumbuhan bobot mutlak ikan lele, seiring dengan pertambahan panjang maka bobot ikan juga bertambah 


\section{Pertumbuhan Kangkung (Ipomoea aquatica) dan Pakcoy (Brassica rapa chinensis)}

Bobot awal kangkung (Ipomoea aquatica) dan pakcoy (Brassica rapa chinensis), yaitu 0.91 gr dan 0.19 gr. Tanaman kangkung dan pakcoy mengalami pertambahan bobot pada akhir pengamatan menjadi 6.46 gr dan 2.65 gr. Hal ini menunjukkan bahwa kangkung dan pakcoy dapat memanfaatkan limbah budidaya ikan untuk pertumbuhan. Laju pertumbuhan spesifik kangkung (Ipomoea aquatica) dan pakcoy (Brassica rapa chinensis) dipengaruhi oleh nutrien di air. Laju pertumbuhan kangkung sebesar 0.06 gr/hari dan pakcoy sebesar 0.07 gr/hari. Laju pertumbuhan kangkung pada penelitian yang dilakukan oleh Jampeetong ${ }^{[45]}$ adalah 0,025 gr/hari. Hal ini menunjukkan bahwa laju pertumbuhan kangkung pada penelitian lebih cepat. Pertumbuhan tanaman dipengarui oleh berbagai faktor, yaitu intensitas cahaya matahari, suhu di daerah akar, suhu lingkungan, $\mathrm{pH}$, konsentrasi nutrien, dan jenis tanaman $[39,46]$.

\section{KESIMPULAN}

Persentase penurunan amonia bebas menunjukkan perbedaan pada perlakuan kontrol, kangkung, dan pakcoy berturutturut adalah 89,16\%, 93,62\%, dan 96,62\%. Perlakuan kangkung efektif dalam meningkatkan tingkat kelangsungan hidup dan laju konversi pakan ikan lele.

\section{DAFTAR PUSTAKA}

(1) Ciptanto S. 2010. Top 10 ikan air tawar, panduan lengkap pembesaran secaraorganik di kolam airterpal, karamba, dan jala apung. Yogyakarta: Lyly Publisher.

(2) Viella S. 2003. Manual On Effluent Treatment in Aquaculture: Science and Practic. Aquaetreat.

(3) Effendi H, Utomo BA, Darmawangsa GM, Hanafiah DA. 2015. wastewater treatment of freshwater crayfish (cherax quadricarinatus) culture with lettuce (lactuca sativa). International Journal of Applied Environmental Sciences. 10(1): 409-420.

Tabel 6. Korelasi parameter kualitas air dan pertumbuhan ikan lele (Clarias sp.)

\begin{tabular}{|c|c|c|c|c|c|c|c|c|c|c|c|c|}
\hline & Suhu & $\mathrm{pH}$ & DO & Amonia & Amonium & Nitrat & Orthofosfat & SR & FCR & $B M$ & PM & SGR \\
\hline Suhu & 1,000 & & & & & & & & & & & \\
\hline $\mathrm{pH}$ & $-0,886^{*}$ & 1,000 & & & & & & & & & & \\
\hline DO & $-0,714$ & 0,771 & 1,000 & & & & & & & & & \\
\hline Amonia & $-0,771$ & 0,543 & 0,600 & 1,000 & & & & & & & & \\
\hline Amonium & $-0,029$ & $-0,371$ & 0,086 & 0,371 & 1,000 & & & & & & & \\
\hline Nitrat & 0,371 & $-0,371$ & $-0,829^{\circ}$ & $-0,257$ & $-0,371$ & 1,000 & & & & & & \\
\hline Orthofosfat & 0,657 & $-0,771$ & $-0,829^{\circ}$ & $-0,429$ & 0,086 & 0,600 & 1,000 & & & & & \\
\hline$S R$ & $-0,714$ & 0,771 & $1,000^{* *}$ & 0,600 & 0,086 & $-0,829^{*}$ & $-0,829^{*}$ & 1,000 & & & & \\
\hline FCR & 0,143 & 0,029 & $-0,429$ & $-0,029$ & $-0,657$ & $0,829^{*}$ & 0,257 & $-0,429$ & 1,000 & & & \\
\hline BM & 0,714 & $-0,771$ & $-1,000^{* *}$ & $-0,600$ & $-0,086$ & $0,829^{*}$ & $0,829^{\circ}$ & $-1,000^{* *}$ & 0,429 & 1,000 & & \\
\hline PM & 0,714 & $-0,771$ & $-1,000^{* *}$ & $-0,600$ & $-0,086$ & $0,829^{*}$ & $0,829^{\circ}$ & $-1,000^{* *}$ & 0,429 & $1,000^{* *}$ & 1,000 & \\
\hline SGR & 0,771 & $-0,771$ & $-0,600$ & $-0,543$ & 0,086 & 0,257 & $0,886^{*}$ & $-0,600$ & 0,029 & 0,600 & 0,600 & 1,000 \\
\hline
\end{tabular}

** korelasi signifikan pada 0,01; korelasi signifikan pada 0,05; SR: tingkat kelangsungan hidup; FCR: laju konversi pakan; BM: bobot mutlak; PM: panjang mutlak; SGR: laju pertumbuhan spesifik 
(4) Arief M, Puspitasari I, Kusdarwati R. 2010. Pengaruh pemberian beberapa bakteri terhadap kelangsungan hidup benih ikan lele dumbo (Clarias sp). Jurnal Ilmiah Perikanan dan Kelautan. 2(2):193-198.

(5) Sikawa DC, Yakupiyiyage A. 2010. The hydroponic production of lettuce (Lactuca sativa 1) by using hybrid catfish (Clarias macrocephalus $\mathrm{x}$ c.gariephinus) pond water: potentials and constraints. Agriculture Water Management. 97:1317-1325.

(6) Effendi H, Utomo BA, Darmawangsa GM. 2015. Phytoremediation of freshwater Crayfish (Cherax quadricaarinatus) culture wastewater with spinach (Ipomoea aquatica) in aquaponic system. Aquaculture, Aquarium, Conservation and Legislation International, Journal of the Bioflux Society. 8(3): 421-430.

(7) Yanong RPE. 2012. Fish health management consideration in recirculating aquaculture system - part 1:Introduction and general principles. Institute of food and agricultural aciences. University of Florida.

(8) McGee M, Circha C. 2000. Principles of water recirculation and filtration in aquaculture. institute of food and agricultural sciences. University of Florida.

(9) Hadiyanto, Christwardana M. 2012. Aplikasi fitoremediasi limbah jamu danPemanfaatannya untuk produksi protein. Jurnal Ilmu Lingkungan. 10(1):32-37.

(10) Paz-Alberto AM, Sigua GC. 2013. Phytoremediation: a green technology to remove enviromental pollutans. American Journal of Climate Change. 2:71-86.
(11) Effendi H, Utomo BA, Darmawangsa GM, Sulaeman N. 2015. Combination of water spinach (Ipomoea aquatica) and bacteria for freshwater crayfish red claw (Cherax quadricarinatus) culture wastewater treatment in aquaponic system. Journal of Advances Biology. 6(3): 1072-1078.

(12) Lestari W. 2013. Penggunaan Ipomoea aquatica Forsk. untuk fitoremediasi limbah rumah tangga. Semirata 2013 FMIPA Universitas Lampung. Lampung, Indonesia. Halaman 441446.

(13) Indah LS, Hendrarto B, Soedarsono P. 2014. Kemampuan eceng gondok(Eichhornia sp.), kangkung air (Ipomoea sp.), dan kayu apu (Pistia sp.) dalam menurunkan bahan organik limbah industri tahu (skala laboratorium). Diponegoro Journal Of Maquares. 3(1):1-6.

(14) Andreeilee BF, Santoso M, Nugroho A. 2014. Pengaruh jenis kompos kotoran ternak dan waktu penyiangan terhadap produksi tanaman pakcoy (Brassica rapa sub. chienensis) organik. Jurnal Produksi Tanaman. 2(3):190-197.

(15) Wibowo S, Asriyanti AS. 2013. Aplikasi hidroponik NFT pada budidaya pakcoy (Brassica rapa chinensis). Jurnal Penelitian Pertanian Terapan. 13(3):159-167.

(16) Dibyantoro, A. L. (1996). Biologi ulat grayak Spodoptera litura F dan daya guna mikrobiota berguna dalam upaya pengendalian hama terpadu ulat grayak. Laporan Hasil Penelitian. Balitsa. Lembang.

(17) [DPP] Directorate Plant Production. 2013. Chinese Cabbage (Brassica rapa L chinensis). Departement Agriculture, Forestry and Fisheries, Republic of South Africa. 
(18) [APHA] American Public Health Assosiation. 2012. Standard method for theexamination of water and waste water. Water Pollution Control Federation. Port City (US): APHA.

(19) EPA [Enviromental Protection Agency]. 2013. Aquatic life ambient water quality criteria for ammonia freshwater. Washington: EPA.

(20) Effendie M. 2002. Biologi Perikanan. Yayasan Pustaka Nusantara. Yogyakarta.

(21) Goddard S. 1996. Feed management in intensive aquaculture. Chapman and Hall.New York (US). P 194.

(22) Affandi R, Tang UM. 2002. Fisiologi hewan Air. Pekanbaru: UNRI Press

(23) Mitchell DS. 1974. Aquatic vegetation and its use and control. Paris(FR): UNESCO

(24) Boyd CE, Lichtkoppler. 1979. Water quality management in pond fish culture. International center for aquaclture. Agriculture Experimental Station. USA.

(25) Bhatnagar A, Devi P. 2013. Water quality guidelines for the management of pond fish culture.International Journal of Environmental Sciences. 3(6):1980-2009. ISSN:0976-4402.

(26) Firmansyah F, Anggo TM, Akyas A. 2009. Pengaruh umur pindah tanam bibit dan populasi tanaman terhadap hasil dan kualitas sayuran pakcoy (Brassica Compestris L., Chinensis group) yang ditanam dalam naungan kasa di dataran medium. Jurnal Agriculture. 20(3):216-224.

(27) Yusuf G. 2008. Bioremediasi limbah rumah tangga dengan sistem simulasi tanaman air. Jurnal Bumi Lestari. 8(2):136-144.
(28) Tarre S, Green M. 2004. High rate nitrification at low ph in suspended and attached biomass reactor. Applied and Environmental Microbiology 70(11):6481-6487.

(29) Ginting C, Rakian TC. 2008. Hidroponik: Pertanian masa depan untuk masyarakat perkotaan. WartaWPTEK. 16:1-5.

(30) Gross A, Boyd CE, dan Wood CW. 2000. Nitrogen transformations and balanced in channel catfish ponds. Aquacultural Engineering. 24:1-14.

(31) Suminto SCP, Sudaryono A. 2014. Gambaran profil darah ikan lele dumbo(Clarias gariepinus) yang diberi pakan dengan kombinasi pakan buatan dan cacing tanah (Lumbriculus rubellus). Journal of Aquaculture.

(32) Adewolu MA, Adeniji CA, Adejobi AB. 2008. Feed utilization, growth and survivalof Clarias gariepinus (Burchell 1822) fingerlings cultured under different photoperiods. Aquaculture. 283:64-67

(33) Hargreaves JA. 1998. Nitrogen biogeochemistry of aquaculture ponds. Aquaculture. 166:181-212.

(34) Effendi H. 2003. Telaah kualitas air bagi pengelolaan sumberdaya dan lingkungan perairan. Kanisius. Yogyakarta. 258 hal.

(35) Wahyuningsih S, Effendi H, Wardiatno Y. 2015. Nitrogen removal of aquaculture wastewater in aquaponic recirculation system. Aquaculture, Aquarium, Conservation and Legislation International, Journal of the Bioflux Society. 8(4):491-499.

(36) Crab R, Avnimelech Y, Defoidt T, Bossier P, Verstraete. 2007. Nitrogen removaltechniques in aquaculture for a sustainable production. Aquaculture. 270:1-14. 
(37) Rijn JV, Tal Y, Schreier HJ. 2006. Denitrification in recirculation system: Theory andaplication. Aquacultur Enginering. 34:364-376.

(38) Pitrianingsih C, Suminto, Sarjito. 2014. Pengaruh bakteri kandidat probiotik terhadap perubahan kandungan nutrien $\mathrm{C}, \mathrm{N}, \mathrm{P}$ dan $\mathrm{K}$ media kultur lele dumbo (Clarias gariepinus). Journal of Aquaculture Management And Technology. 3(4):247-256.

(39) Buzby KM, Lian Shin L. 2014. Scaling aquaphonic systems: balancing plant uptake with fish output. Aquacultur Engineering. 63:39-44.

(40) EPA [Enviromental Protection Agency]. 2000. Introduction to phytoremediation. Washington: EPA.

(41) Nugroho RA, Pembudi LT, Chilmawati D, Haditomo AHC. Aplikasi teknologi Aquaponik pada budidaya air tawar untuk optimalisasi kapasitas produksi. Jurnal Saintek Perikanan. 8(1): 4651.

(42) Jimoh WA, Fagbenro OA, Adeparusi EO. 2014. Response of African Catfish,

(43) Clarias gariepinus (Burchell 1822), fingerlings fed diets containing differently timed wet-heat-treated sesame (Sesamum indicum) Seedmeal. Agricultural Sciences. 5:1159-1171.
(44) Dasuki A, Auta J, Oniye SJ. 2013. Effect of stocking density on productionof Clarias gariepinus (tuegels) in floating bamboo cages at Kubanni Reservior, Zaria, Nigeria. Bajopas. 6(1):112 - 117.

(45) Mufidah NBW, Rahardja BS, Satyantini WH. 2009. Pengkayaan Dapnia spp.dengan viternaterhadap kelangsungan hidup dan pertumbuhan larva ikan lele dumbo (Clarias gariepinus). Jurnal Ilmiah Perikanan Dan Kelautan. 1(1):59-65.

(46) Jampeetong A, Brix H, Kantawanichkul S. 2012. Effects of inorganic nitrogen forms on growth, morphology, nitrogen uptake capacity and nutrient allocation of four tropical aquatic macrophytes (Salvinia cucullata, Ipomoea aquatica, Cyperus involucratus, and Vetiveria zizanioides). Aquatic Botany. 97:1016.

(47) Nurkemalasari R, Sutisna M, Wradhani E. 2013. Fitoremediasi limbah cair dengan menggunakan tumbuhan kangkung air (Ipomoea aquatica). Reka Lingkungan. 1(2):1-12. 